\title{
Introduction - Localising Governance: An Outlook on Research and Policy*
}

\author{
Anuradha Joshi and Markus Schultze-Kraft
}

\begin{abstract}
The past two decades have seen an enormous increase in academic and policy attention to, and engagement with, governance at the sub-national and local levels. Yet, our understanding of the conditions that enable local governments to deliver services to citizens, reduce poverty, be inclusive and responsive, bridge cleavages in divided post-conflict societies or represent citizen interests to higher levels of authority remains limited. Drawing on different perspectives, the articles contained in this IDS Bulletin take a fresh look at how local governance 'really' works and how it could become more accountable, effective and legitimate to support development that favours poor and marginalised people. Extending the boundaries of prevailing debates on methodological and conceptual issues, civil society, political and power relationships, and the challenges of decentralisation in (post)-conflict settings, the authors offer an outlook on taking forward the work on localising governance and designing policies that help improve its performance.
\end{abstract}

\section{Introduction}

Over the past two decades, academic and policy engagement with governance at the sub-national and local levels has increased enormously. The focus on 'the local' itself is not new: researchers working on public administration and decentralisation have for a long time been interested in local governance as a means for improving service delivery (Cheema and Rondinelli 1983; Conyers 1983; Mawhood 1983; Smith 1985). What is new is that a much wider group of scholars - from economists and political scientists to anthropologists and sociologists - as well as increasing numbers of practitioners working in fields as diverse as rural development and peace-building have, for different reasons, developed a keen interest in local governance. ${ }^{1}$

Broadly speaking, two schools of thought on 'the local' can be discerned. One strand, rooted in neoliberal perspectives, is concerned with the promotion of political pluralism and questions the relevance of the central state in the development process. In this view, decentralisation and the delegation of authority from the central to the local levels are essentially viewed as key vehicles for the more effective and (market)-efficient provision of basic public services and goods (Shah and Thompson 2004;
Batley 2004; Ahmad and Devarajan 2005;

Robinson 2007b; Faguet 2014). The other strand is inspired by concerns over what are perceived to be significant shortcomings of liberalrepresentative democracy, particularly with respect to citizen representation and participation in the political process. The local arena and civil society are seen as pivotal to enhance participatory practice and improve the responsiveness of the state to citizen demands (Olowu and Wunsch 2004; Ribot 2003; Baviskar and Matthew 2009; Gaventa 2004; Crook and Manor 1998). Thus, guided by two quite fundamentally different outlooks on the development process, 'the local' has moved centre stage in efforts to promote socioeconomic development, reduce poverty, establish more accountable and legitimate political institutions and orders, and prevent or end violent conflict.

The decentralisation waves that swept many parts of Africa, Asia and Latin America over the 1980s, 1990s and 2000s are testimony to this growing attention to, and engagement with, local governance. They embody the high hopes (presented in very different guises) that both 'neoliberal' and 'liberal-democratic' perspectives placed on 'development from below'. Yet, despite the accumulated wealth of experience, we have 
limited understandings of the conditions that enable local governments to deliver services to citizens, reduce poverty, be inclusive and responsive, reduce cleavages in divided postconflict countries or represent citizen interests to higher levels of authority (Scott 2009; Robinson 2007a; Roeder and Rothchild 2005). Many observers point to the significant challenges for governance and development at the local level, including accountability deficits, elite capture of local institutions, a weak rule of law, and a propensity of local politics to reflect established power relationships at the central government and state level (Bardhan and Mookherjee 2006; Cheema and Rondinelli 2007; Ribot and Oyono 2005; Crook and Sverrison 2003). It appears that overall, the evidence of a positive correlation between decentralisation and improved local governance is mixed: in some contexts local governments are successful in delivering on the expectations placed upon them in terms of improving transparency and accountability, and maintaining political stability; while in others they are not (Faguet 2013; Faguet 2014). Simultaneously, despite significant donor support for strengthening local civil society organisations, demand for good governance from below too, has achieved success only sporadically and in uneven fashion (Blair 2000; Cornwall and Coelho 2006).

These experiences have prompted shifts in the focus on 'the local'. On the one hand, the literature on decentralisation, including that in (post-)conflict settings, increasingly acknowledges that delegating authority (and resources) is not enough (García Villegas et al. 2011; Manning 2003). Greater attention needs to be placed on the difficult issues of the capacity and incentives of the local state and the wider social and political context at the local level. On the other hand, the advocates of civil society also recognise that civic action alone cannot lead to improved public goods; state capacity and willingness to respond is necessary for civil action to have the most traction (McGee and Gaventa 2011).

How, then, might local and decentralised governance better deliver on its promise of effective and locally accountable public authority?

In the autumn of 2012, as part of a Swiss Agency for Development and Cooperation (SDG) collaboration with the Institute of Development
Studies (IDS) to support SDC's Decentralisation and Local Governance Network (DLGN), a group of researchers at IDS was asked to take a fresh look at the broad theme of how local governance 'really' works and how it could become more accountable, effective and legitimate in order to support development that favours poor and marginalised people. The results of this work are presented in this IDS Bulletin. Rather than a set of contributions that speak to one overarching question, the articles represent a panoply of different perspectives on 'the local'. They extend the boundaries of prevailing debates on four fronts.

First and foremost, the articles push the methodological and conceptual boundaries of the study of 'the local'. They offer fresh perspectives on understanding features of the local context, citizens' responses to violence and international interventions, as well as the challenges that are associated with the creation of legitimacy from below. The authors emphasise the importance of taking into account invisible structures of power that constrain the agency of the poor and most marginalised and highlight the role - both positive and negative - of informal institutions in local governance processes. Understanding the context, they suggest, requires a more nuanced and amplified conception of political and power relationships.

Second, the articles take on the issue of local civil society. In the past decade, the significant attention given to civil society and its role in generating 'demand for good governance' has largely focused on those civil society organisations (CSOs) that are generally viewed as playing a positive role (e.g. NGOs, human rights organisations, etc.). Yet the range of C.SOs that are relevant to development outcomes is larger than usually acknowledged and includes also traditional formations, religious institutions, criminal networks, trade unions, and insurgent and terrorist groups. Several contributions to this IDS Bulletin argue for greater attention to such unusual suspects, particularly in contexts where conventional civil society is weak or nonexistent, and where state structures are fragile, conflict-prone or affected by violence. This is complemented by the call for an expanded understanding of civil society as comprising not just organised groups and civic associations, but also a range of unorganised forms of mobilisation, 
such as spontaneous protests, social media campaigns and manifestations of unruly politics: what some commentators have called 'political society' (Chatterjee 2004; khanna 2012).

Third, the articles emphasise 'the political' in local governance. Although development thinking has long moved beyond technical conceptions of local governance, and there is widespread acceptance of the need to work more 'politically', such work has often centred on analysing the incentives and interests of different (national) stakeholders to understand the potential drivers of, and constraints to, change - using classic political economy lenses. The role of hidden and invisible power, informal institutions, international security and geopolitical agendas, and powerful narratives that shape development discourse and practice have been less well explored. A number of articles in this IDS Bulletin begin to address this agenda.

Finally, some of the studies contribute to the particular understandings and challenges of decentralisation in conflict and post-conflict situations. Expectations of decentralisation in such contexts are high and decentralisation has been used quite extensively in peace-building efforts since the end of the Cold War. However, there is little empirical evidence that it contributes positively to reducing conflict and ethnic tensions, promoting social inclusion, strengthening social cohesion, generating trust, or enhancing legitimacy (Lake and Rothchild 2005; Manning 2003; Roeder and Rothchild 2005; for exceptions see Ghai 1998; Jackson and Scott 2007).

The remainder of this introduction takes up each of these four themes, identifies the contributions that the articles make and situates them within wider current development debates.

\section{Pushing methodological and conceptual boundaries}

In recent years, much of the work on governance and development (including local governance) has been characterised by three big features: (1) a recognition that one needs to pay attention to politics: 'thinking and acting politically'; (2) a concern with the impacts of governance and development interventions; and (3) a focus on citizen action - 'the demand for good governance'. The first three articles in this IDS Bulletin develop new conceptual approaches to tackling these issues.
Understanding politics and working politically in developmental contexts is a growing concern in aid and development debates (Carothers and de Gramont 2013). Zeroing in on this issue, Pettit and Mejía Acosta point out that working with political economy analysis (PEA) is not enough; one needs to pay attention also to the location of different types of power and how they operate. While PEA helps identify the incentives and institutions that might constrain or support change, power analysis (PA) helps identify the invisible power structures that constrain poor and marginalised groups from even imagining that change is possible, or from acting on injustice even when it is named. Ultimately, Pettit and Mejía Acosta argue, combining PEA and PA will allow for a more robust and multi-faceted analysis, which can help to reveal, challenge and test prevailing development narratives and the theories of change that underlie interventions.

\section{Complementing the call for combining} approaches to analysing local political dynamics and processes, in her contribution Joshi separates for analytical purposes, the macrofeatures of context from the more immediate micro-features. She argues that unpacking the assumptions behind each step of how change is expected to happen - a causal chain - can help to understand more precisely which local contextual conditions are relevant and how they might enable or constrain change. Such an analysis of context is relevant to the current concerns about tracing the impact of development programmes and the related 'results agenda'. While much effort has gone into developing sophisticated (particularly econometric) methods for isolating the effects of specific interventions, through randomised controlled trials, the question of why and how impacts are achieved in specific and different contexts remains. Using the case of social accountability interventions, unpacking underlying theories of change and their component causal chains, she argues, can not only help to understand constraints and opportunities, but also help assess impact by examining the extent to which interventions travelled along particular causal chains.

One of the unspoken assumptions of local governance interventions is that of claim-making by citizens. The recent spate of work on participatory governance calls for harnessing 
citizen action and raises the question of what drives such action. The article by McGee presents a conceptual framework for 'seeing like a citizen' in violence and conflict-affected contexts. By situating the possibilities for citizen action in lived realities at the local level she shows how public authority at the local level is negotiated between a variety of state and nonstate actors, including perpetrators of violence, some of whom may be state agents. A citizen'seye view of the construction of authority and legitimacy at the local level in violent contexts enables us to see the possibilities and limits of citizen action. While this 'voices of the poor' approach is not new, the article pushes us to think deeply about the processes and structures within which citizen action and voice are located and how they shape local political agency.

\section{Expanding the thinking on 'civil society'}

The approach of 'seeing like a citizen' outlined above calls for a rethink of what we mean by civil society and what role it plays in local democracy and governance. As noted earlier, against the backdrop of concerns over the shortcomings of liberal-representative democracy, there has been an increased interest in ways of deepening democracy through citizen engagement and participation. A key issue here is the question about how citizens can actively and meaningfully shape the course and outcomes of political processes beyond participating in elections. For the most part, this interest has in the past focused on civil society organisations and their direct participation in governance processes.

The article by McGee and the first article by Tadros re-emphasise the agency and role of citizens in creating political authority in local settings, but look beyond conventional CSOs. Viewed at through this lens, citizens are perceived as 'makers and shapers' rather than 'users and choosers', playing an important role in 'complex power dynamics linking them to both institutions and to other citizens in various organisational forms'. Indeed, as McGee points out, 'The most relevant interfaces and dynamics of "governance" often lie not between citizens and state, but within the citizenry and within the community... between different kinds of organised social actors [and] between citizens and non-state actors...'.

This perspective opens up the possibility to go beyond traditional conceptions of civil society and
CSOs and explore the relationships between a wider universe of social actors, who may take on different (formal and informal) organisational forms or, indeed, may not be organised at all, emerging rather as spontaneous movements working through unruly politics. Mohmand and Mihajlovic, in their analysis of informal local governance institutions in the Western Balkans the mesni zajednicas (MZs) - make the point that while citizen participation in formal participatory spaces is low, MZs, which 'lie neither wholly in the public formal realm, nor fully in the informal', seem to be playing an important role in connecting citizens to the state. Tadros, in turn, argues that we need to look at unorganised forms of civil society action. Her analysis of the unexpected trajectory of the Egyptian revolution in 2011 and its aftermath points to the importance of this approach - capturing the pulse of ordinary citizens was central to explaining how events unfolded in ways that were not predicted through conventional civil society analyses by external observers.

\section{Zeroing in on local politics}

Since the early 1990s, most development scholars and practitioners have acknowledged that to be successful, development programmes need to be sensitive to the politics of local contexts (Unsworth 2009). In practice, this has usually not meant much more for donors than carrying out political and political economy analyses of country contexts and using them as background guidance for their programming. Yet, as Rocha Menocal points out, the real challenge lies in moving from thinking politically to actually working differently (Rocha Menocal 2014). Part of the problem is that PEA and related approaches, while good at identifying institutional incentives and the interests of stakeholders, are not as effective when it comes to appreciating the importance of their tacit knowledge, their (overt and covert) social and political networks and relationships, or the power dynamics that structure them.

Working more politically also means working more explicitly on issues related to the organisation and functioning of the political system, such as those of democracy and democratisation. Democracy is based on the key principles of citizen control over public decisionmaking, inclusive participation, political equality and accountability. We see democracy - both 
normatively and empirically - as an essential element for understanding the mechanisms of local governance, and as an element that serves to highlight and reinforce certain aspects of 'good' local governance, including the linkages to the regional and national levels.

Appreciating the political context and highlighting the implications it has for governance, development and peace is a theme that, in one form or another, runs through all of the articles in this IDS Bulletin. As the articles illustrate, local governance should be conceived not merely as a formal relationship between central and local governments, but as a complex set of political relationships between many different actors - formal and informal, national and local - which interrelate with each other in diverse ways. These actors and relationships have to be disaggregated in order to understand their political and technical determinants and the nature and impact of the various interconnections. This is well illustrated in the article by Arellano Yanguas and Mejía Acosta (this IDS Bulletin): while natural resource revenue allocations to local governments can be set by various logical criteria, how these are distributed in practice in different countries depends upon the degree of bargaining power of sub-national actors, and the linkages between national and sub-national actors.

Other contributions offer additional insights into these political relationships and how they affect local governance and the prospects for development and peace in distinct settings. In this respect, Schultze-Kraft and Morina highlight the problematic role of patron-client relationships in post-conflict/independence Kosovo. Undercutting the potential of Kosovo's decentralised system to strengthen local governance and accountability, these relationships structure the exchanges between citizens (regardless of their ethnic identity) and local political leaders. Clientelistic dependencies and transactions extend right up from the local level to the political party leadership in the central government, the international peace- and state-building apparatus and, a particular feature of the Kosovo case, the Serbian government in Belgrade.

The authors thus challenge the implicit belief often found among international development agencies that successful experiences of local governance can simply be scaled up through replication and aggregation. This view on how to achieve broader societal impacts is, as some articles suggest, quite inaccurate. Increasing the scale of impacts is not simply a matter of isolating the local state, understanding how to make it work, and replicating. Rather, it requires us to think about the place of local specificities within larger political structures, i.e. the relationship of the local state with national and international power holders, as well as its relationship with social actors. Identifying the key issues around which such relationships are structured, is one of the critical agendas for the future.

\section{Understanding decentralisation in (post-) conflict settings}

A key factor behind the growing attraction of decentralisation in countries embroiled in, or emerging from, violent conflict, has been the expectation that it helps provide political stability and defuse ethnic and other identitybased conflicts. The idea is that decentralisation helps mitigate the risk of violence by devolving control over public resources and decisionmaking responsibilities to local levels. More responsive and accountable local governments, it is held, can better meet the needs of different social and ethnic groups and thus bridge deep cleavages and protect the fundamental rights of minorities. In addition, by devolving authority states can reduce demands for secession and the break-up of the state (Faguet 2014; Lake and Rothchild 2005). While these expectations ring true in theory, we have little empirical evidence that would support the claim that on its own decentralisation contributes to peace and (democratic) stability.

Among the reasons that explain this gap between theory and reality, Schultze-Kraft and Morina point out (this IDS Bulletin), are the possibilities that:

decentralisation may increase the risk of elite capture of local governments and result in the strengthening of informal patronage networks and patron-client relationships; that local governments may be unable to raise sufficient financial resources to provide services effectively; that decentralisation can entail the loss of economies of scale; and that there may be a heightened risk of corruption and 
the misuse of public authority and resources at the local government level.

These problems are closely related to the weaknesses of accountability mechanisms at the local level and between local and higher levels of authority. They are compounded in war-to-peace transitions in ethnically divided countries where decentralisation is used simultaneously as a tool to protect the civil and political rights of minorities and a means of building a democratic and stable state. The negative trade-offs between the 'political' and 'functional' dimensions of decentralisation in countries emerging from internal conflict are illustrated by Schultze-Kraft and Morina in their examination of the case of Kosovo.

Mohmand and Mihajlovic complement this analysis by focusing on the role of the abovementioned mesni zajednicas (MZs) in Bosnia and Herzegovina, Croatia, Macedonia and Serbia. Finding that despite decentralisation, citizen participation in local governance processes is very low in these countries, the authors posit that MZs are filling this void by 'allowing citizens to participate and communicate their needs to municipal governments... [and ] also have the potential to play a direct role in service provision'.

In her second article in this IDS Bulletin, Tadros adds another dimension to this debate by focusing on the informal devolution of powers from the central to the local level of government with respect to the management of sectarian incidents in Egypt's volatile post-Mubarak setting. 'One of the most dramatic changes occurring after the revolution', she writes, 'is in the shift in the management of sectarian incidents on a local level from the SSI [state security investigations] apparatus to that of the Muslim Brotherhood and the Salafis'. This process has been reflected in the establishment of informal committees for administering local justice, which are not accountable to anyone and have contributed to deepening cleavages between Muslims and Christians.

\section{Outlook on future research and policy}

The collection of articles contained in this IDS Bulletin chart out several promising avenues for taking forward the work on localising governance and designing policies that help improve its performance. While these are not the only avenues that deserve attention, they do point to several issues that require deeper thought on the part of both scholars and policymakers.

To be sure, the task ahead is quite formidable. This is particularly so because translating the methodological and conceptual innovations outlined in the contributions to this IDS Bulletin is no small challenge. Essentially, it entails re-thinking many of the existing approaches to strengthening local governance, service delivery and democracy, and assessing the impact of interventions. To guide future interventions and programming in this complex area, policymakers need to:

a Focus more consciously and in a more encompassing way on local contexts and political and power relationships between a broader range of local state and non-state actors and stakeholders;

b Be clearer about the relationships and interdependencies between what happens (or does not happen) at the local level, on the one hand, and at the national and international levels on the other;

c Be more attuned to the role of invisible power, informal institutions, international security and geopolitical agendas, and powerful narratives that shape development discourse and practice;

d Engage more effectively in (post-)conflict settings, where decentralisation on its own has proven to be of limited help in reducing violent conflict, bridging ethnic and other identity-based cleavages, promoting social inclusion and cohesion, generating trust, and enhancing the legitimacy of the (local) political order.

Drawing on a variety of perspectives, the articles in this IDS Bulletin provide a number of pointers as to how the above issues could be addressed. But there is certainly a need for more multidisciplinary and inter-disciplinary research on the complexities involved in making local governance in poor and/or conflict-affected countries more responsive, inclusive and effective. 


\section{Notes}

* Thanks to Diana Conyers and Jethro Pettit for very useful suggestions. We have also benefited from discussions at a seminar at IDS on 1 March 2013, where early drafts of this set of articles were presented.

\section{References}

Ahmad, J. and Devarajan, S. (2005) Decentralization and Service Delivery, Policy Research Working Paper 3603, Washington DC: World Bank

Bardhan, P. and Mookherjee, D. (2006) 'The Rise of Local Governments: An Overview', in P. Bardhan and D. Mookherjee (eds) (2006), Decentralization and Local Governance in Developing Countries. A Comparative Perspective, Cambridge MA and London: MIT Press

Batley, R. (2004) 'The Politics of Service Delivery Reform', Development and Change 35.1: 31-56

Baviskar, B.S. and Matthew, G. (eds) (2009) Inclusion and Exclusion in Local Governance: Field Studies from Rural India, New Delhi: Sage (for Institute of Social Sciences)

Blair, H. (2000) 'Participation and Accountability at the Periphery: Democratic Local Governance in Six Countries', World Development 28.1: 21-39

Carothers, T. and de Gramont, D. (2013) Development Aid Confronts Politics, Washington DC: Carnegie Endowment for International Peace

Chatterjee, P. (2004) The Politics of the Governed: Reflections on Popular Politics in Most of the World, New York: Columbia University Press

Cheema, G.S. and Rondinelli, D.A. (eds) (2007) Decentralizing Governance. Emerging Concepts and Practices, Washington DC: The Brookings Institution Press

Cheema, G.S. and Rondinelli, D.A. (eds) (1983) Decentralisation and Development, London: Sage Publications

Conyers, D. (1983) 'Decentralisation: The Latest Fashion in Development Administration', Public Administration and Development 31: 97-109

Cornwall, A. and Coelho, V.S. (eds) (2006) Spaces for Change?, London: Zed Press

Crook, R. and Manor, J. (1998) Democracy and Decentralisation in South Asia and West Africa, Cambridge University Press

Crook, R. and Sverrisson, A. (2003) 'Does Decentralization Contribute to Poverty Reduction?', in P. Houtzager and M. Moore (eds), Changing Paths: International Development and the New Politics of Inclusion, Ann Arbor: University of Michigan Press
1 Witness the recent special issue of World Development devoted to the theme of Decentralisation and Governance, with contributions from a range of social science disciplines (see Faguet 2014).

Faguet, J.-P. (2014) 'Decentralization and Governance', World Development 53: 2-13

Faguet, J.-P. (2013) 'Can Subnational Autonomy Strengthen Democracy in Bolivia?, Journal of Federalism 44.1: 51-81

García Villegas, M.; García Sánchez, M.; Rodriguez Raga, J.; Revelo Rebolledo, J. and Espinosa Restrepo, J. (eds) (2011) Los Estados del País. Instituciones Municipales y Realidades Locales, Bogotá: De Justicia

Gaventa, J. (2004) 'Towards Participatory Local Governance: Assessing the Transformative Possibilities', in S. Hickey and G. Mohan (eds), Participation: from Tyranny to Transformation, London: Zed Books

Ghai, Y. (1998) 'Decentralisation and the Accommodation of Ethnic Diversity', in C. Young (ed.), Ethnic Diversity and Public Policy, Geneva: United Nations Research Institute for Social Development (UNRISD)

Jackson, P. and Scott, Z. (2007) Local Government in Post-Conflict Environments, Report to UNDP, University of Birmingham, UK

khanna, a. (2012) 'Seeing Gitizen Action through an "Unruly" Lens', Development 55.2: 162-72

Lake, D. and Rothchild, D. (2005) 'Territorial Decentralization and Civil War Settlements', in P. Roeder and D. Rothchild (eds), Sustainable Peace: Power and Democracy after Civil Wars, Ithaca and London: Cornell University Press

Manning, G. (2003) 'Local Level Challenges to Post-conflict Peace-building', International Peacekeeping 10.3: 25-43

Mawhood, P. (1983) Local Government in the Third World, Chichester: Wiley

McGee, R. and Gaventa, J. (2011) Shifting Power? Assessing the Impact of Transparency and Accountability Initiatives, IDS Working Paper 383, Brighton: IDS

Olowu, D. and Wunsch, J. (eds) (2004) Local Governance in Africa: the Challenges of Democratic Decentralisation, London: Lynne Riemer

Ribot, J. (2003) African Decentralization: Local Actors, Powers and Accountability, Geneva: United Nations Research Institute for Social Development (UNRISD) 
Ribot, J.C. and Oyono, P.R. (2005) 'The Politics of Decentralisation', in B. Wisner, C. Toulmin and R. Chitiga (eds), Towards a New Map of Africa, London/Sterling VA: Earthscan

Robinson, M. (ed.) (2007a) 'Introduction: Decentralizing Service Delivery? Evidence and Policy Implications', IDS Bulletin 38.1: 1-6

Robinson, M. (2007b) 'Does Decentralization Improve Equity and Efficiency Public Service Delivery Provision?', IDS Bulletin 38.1: 7-17

Rocha Menocal, A. (2014) Getting Real about Politics: From Thinking Politically to Working Differently, London: Overseas Development Institute (ODI)

Roeder, D. and Rothchild, P. (2005) 'Dilemmas of State-building in Divided Societies', in D. Roeder and P. Rothchild (eds), Sustainable Peace: Power and Democracy after Civil Wars, Ithaca and London: Cornell University Press
Scott, Z. (2009) Decentralisation, Local Development and Social Cohesion: An Analytical Review, GSDRC Research Paper, Birmingham: International Development Department

Shah, A. and Thompson, T. (2004) Implementing Decentralised Local Governance: A Treacherous Road with Potholes, Detours and Road Closures, Policy Research Working Paper 3353, Washington DC: World Bank

Smith, B. (1985) Decentralisation. The Territorial Dimension of the State, London: George Allen and Unwin

Unsworth, S. (2009) 'What's Politics Got to Do with It?: Why Donors Find it So Hard to Come to Terms with Politics, and Why This Matters', Journal of International Development 21.6: 883-94 